\title{
Primary Aneurysmal Bone Cyst of the Cervical and Cervico-thoracic Regions of the Spine
}

\author{
Hany El Zahlawy*, Mohammed Zayan Ibrahim, Ahmed Elbadrawi and Mohammed Abdelsalam Wafa \\ Department of Orthopedics, Ain Shams University, Egypt
}

Submission: December 8, 2017; Published: December 19, 2017

*Corresponding author: Hany El Zahlawy, Department of Orthopedics, Ain Shams University, 18 Rabaa Housing Project, El Nasr city, Cairo, Egypt, Tel: +201002508641; Fax: +20224509378; Email: hzahlawy@hotmail.com

\begin{abstract}
Background: Primary aneurysmal bone cyst (ABC) is a locally aggressive neoplasm associated with bone destruction. The aim of this study is to present treatment options and their outcomes in $\mathrm{ABC}$ involving the cervical spine and the cervico-thoracic junction.

Patients and Methods: Six patients with ABC of the spine were surgically treated. The cervical spine was involved in four and the cervicothoracic junction in two. The patients' complains were recorded. Their pain was scaled on VAS. Their neurologic status was graded according to Frankel. All patients were evaluated preoperatively with plain radiographs, CT scan and MRI. The surgical approaches and stages were documented for each case. The patients were followed up for a minimum of 2 years. Any improvement in pain and neurologic status was noted. Follow up images were assessed for any construct failure or recurrence.

Results: All patients presented with axial pain (VAS 5.7). Two complained of radicular pain and one of neck swelling. Three patients were neurologically intact, one was grade D and another grade C. Piecemeal tumor resection was performed. Dual approach was done with anterior corpectomy and reconstruction. This was combined with posterior intralesional curettage or resction of the affected posterior spinous elements and fixation. The mean VAS for pain improved to 2.3 at final follow up. No case showed neurologic deterioration after surgery. At final follow up, the patients with preoperative neurologic deficits showed full recovery to Frankel E. Recurrence was noted radiologically in two cases involving the posterior spinous elements.
\end{abstract}

Keywords: Aneurysmal bone cyst; Cervical cervico-thoracic spine; Surgical excision

Abbreviations: ABC: Aneurysmal Bone Cyst

\section{Introduction}

Primary aneurysmal bone cyst (ABC) is a locally aggressive tumor like neoplasm associated with bone destruction. It is a vascular neoplasm with most cases occurring in the first two decades of life with slight female predominance [1,2]. It represents $1 \%$ of bone tumors and $15 \%$ of primary spine tumors. In the spine, it usually affects the posterior elements of the vertebra with occasional extension into the spinal canal, vertebral body and paravertebral soft tissues. Despite being more common in the lumbar region, the cervical and thoracic spines may occasionally be affected [3-5]. Patients usually present with localized axial pain, persistent even with rest. Plain radiographs reveal expansile osteolytic lesions with thin rims. Characteristically, fluid-fluid level may be seen with CT and MRI $[4,6,7]$. Management of ABC of the spine is challenging with surgical resection or curettage being performed mainly. Selective arterial embolization may be performed prior to surgery to reduce bleeding, or occasionally as the sole method of treatment. Radiotherapy and cryotherapy have also been described $[3,4,7]$. The aim of this study is to present treatment options and their outcomes in $\mathrm{ABC}$ involving the cervical spine and the cervico-thoracic junction, through cases which have been treated in our department.

\section{Patients and Methods}

Six patients with $\mathrm{ABC}$ of the spine were surgically treated in Ain Shams university hospitals between 2008 and 2015. Four of them were females and 2 were males. Their mean age was 13.8 years (range 10-22 years). The cervical spine was involved in four and the cervico-thoracic junction in two cases. The tumor was localized to a single vertebral level in five cases while involving two adjacent levels in a solitary case. One patient presented to us after initial surgical treatment elsewhere. The patient's complaints at presentation were recorded. Their pain was scaled on VAS. Their neurologic status was graded according to Frankel. All patients were evaluated preoperatively with plain radiographs, CT scan and MRI. Preoperative biopsy was performed in all to confirm the diagnosis under CT guidance without any notable problems. 
Preoperative selective arterial embolization was attempted in four cases the day before the surgery. The surgical approaches and stages were documented for each case. Mean operative time and blood loss were also recorded. The patients were followed up for a minimum of 2 years. Any improvement in pain and neurologic status was noted according to VAS and Frankel's grade respectively. Patients were followed up radio logically at monthly interval during the first 3 months after surgery and every 3 months thereafter. The images were assessed for any construct failure or recurrence.

\section{Results}

Clinically all patients presented with axial pain (their mean VAS was 5.7). In addition, two of them were complaining of radicular pain (brachialgia) and a single case with obvious neck swelling. Three patients were neurologically intact (Frankel E) at presentation; one was grade $\mathrm{D}$ and another grade $\mathrm{C}$. The mean duration of symptoms was 5 months. The tumor involved both posterior and anterior elements of the vertebra in five cases with expansion and osteolysis in CT scan. In a single case the lesion was confined to the body and odontoid process of C2. MRI revealed low signal intensity in T1- weighted images and Table 1: The patients are summarized.

\begin{tabular}{|c|c|c|c|c|c|c|}
\hline Case & Age & Sex & Level & $\begin{array}{c}\text { Duration of } \\
\text { Symptoms } \\
\text { (m) }\end{array}$ & Presentation & Rurgical Procedure \\
\hline 1 & $10 \mathrm{y}$ & $\mathrm{M}$ & $\mathrm{T} 1+\mathrm{T} 2$ & 12 & $\begin{array}{c}\text { Neck pain + swelling + } \\
\text { paraparesis (Frankel C) }\end{array}$ & $\begin{array}{c}\text { Anterior corpectomy + reconstruction + } \\
\text { posterior excision and fixation }\end{array}$ \\
\hline 2 & $11 \mathrm{y}$ & $\mathrm{M}$ & $\mathrm{T} 1$ & 3 & $\begin{array}{c}\text { Neck pain + paraparesis } \\
\text { (Frankel D) }\end{array}$ & $\begin{array}{c}\text { Anterior corpectomy + reconstruction + } \\
\text { posterior excision and fixation }\end{array}$ \\
\hline 3 & $22 \mathrm{y}$ & $\mathrm{F}$ & $\mathrm{C} 4$ & 9 & Neck pain & $\begin{array}{c}\text { Anterior corpectomy + reconstruction }+ \\
\text { posterior curettage and fixation }\end{array}$ \\
\hline 4 & $18 \mathrm{y}$ & $\mathrm{F}$ & $\mathrm{C} 2$ & 2 & Neck pain & $\begin{array}{c}\text { Anterior corpectomy + reconstruction }+ \\
\text { posterior fixation }\end{array}$ \\
\hline 5 & $15 \mathrm{y}$ & $\mathrm{F}$ & $\mathrm{C} 5$ & 3 & Neck pain + Radicular pain & $\begin{array}{c}\text { Anterior corpectomy + reconstruction }+ \\
\text { posterior excision and fixation }\end{array}$ \\
\hline 6 & $18 \mathrm{y}$ & $\mathrm{F}$ & $\mathrm{C} 6$ & 1 & Neck pain + Radicular pain & $\begin{array}{c}\text { Anterior corpectomy + reconstruction }+ \\
\text { posterior curettage and fixation }\end{array}$ \\
\hline
\end{tabular}

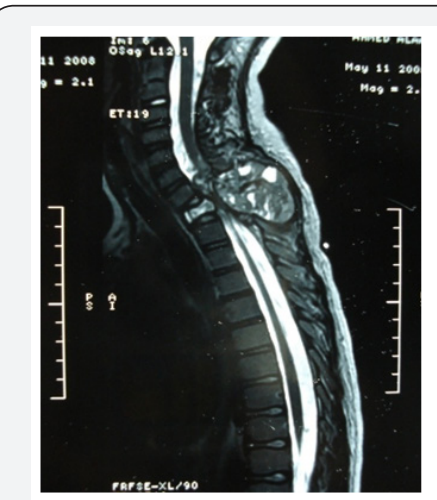

A

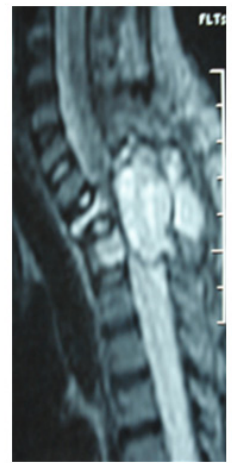

B

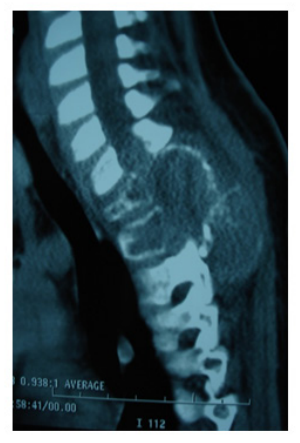

C

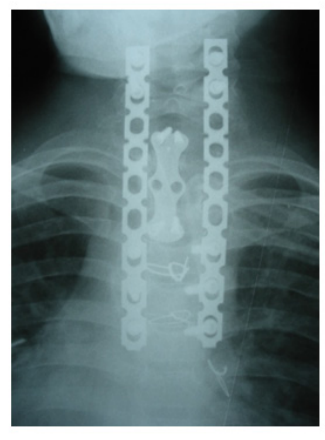

D

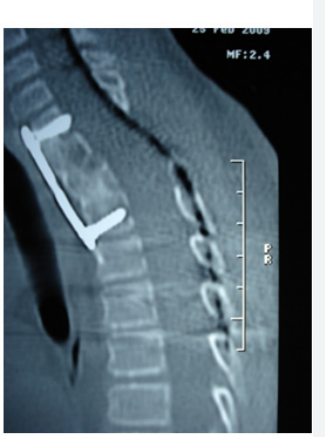

$\mathrm{E}$

Figure 1: $A 10$ years old boy had presented with severe neck pain and had been treated by wide laminectomy for $A B C$ of $T 1$ elsewhere. 3 months after the initial procedure he presented to us with paraparesis (Frankel C). (A) Initial MRI. (B, C) MRI and CT on referral to our institute. Note tumor extension to T2. (D) Total excision was performed with posterior fixation, anterior corpectomy and reconstruction via iliac crest graft and a plate. (E) CT 6 months after surgery. Patient showed complete neurologic recovery (Frankel E). 


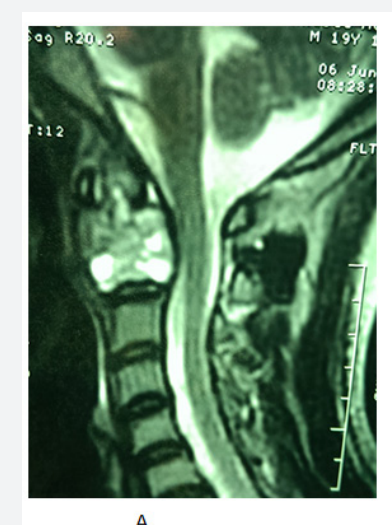

A

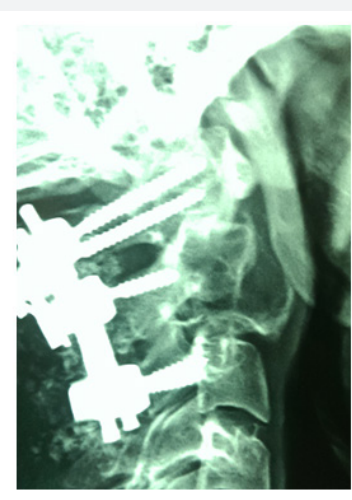

B

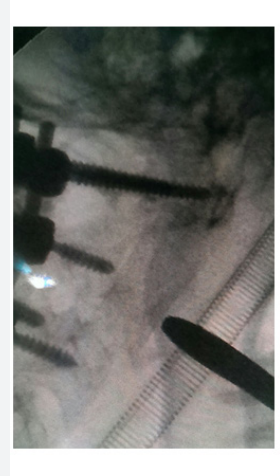

$\mathrm{C}$

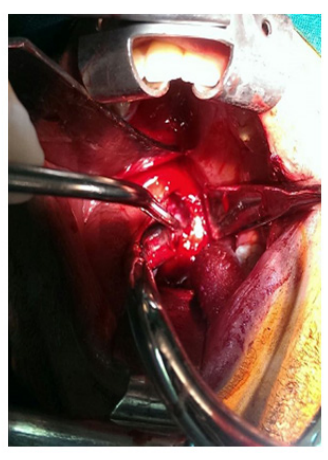

D

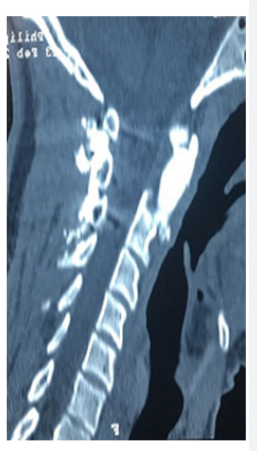

Figure 2: An 18 years old female presented with neck pain. $A B C$ of $C 2$ was diagnosed by images and biopsy. Surgical excision and reconstruction were performed on 2 stages. (A) Preoperative MRI. (B) Plain radiograph following the posterior procedure (C1-C3 fixation). (C, D) lliac strut insertion following anterior corpectomy via trans-oral approach. (E) Postoperative CT after 3 months.

\section{Discussion}

Relentless pain is the most common presentation for patients with $\mathrm{ABC}$ of the spine, being reported in more than $90 \%$ of cases in various studies [4,7]. All cases in our series presented with pain. Neurologic deficit was found in 33\% of our cases which is comparable to their incidence in the literature (10$40 \%)[3,7]$. The mean age of our patients was 13.8 years with female predominance $(66 \%)$. This is in line with the literature which states its occurrence in the first two decades of life [8]. Although biopsies should be performed to confirm the diagnosis, care should be taken as the bloody nature of the lesions could lead to complications $[9,10]$. We obtained biopsies for all our cases under CT guidance prior to surgery without any notable complications. In addition, Chao et al. reported mere $43 \%$ accuracy of needle biopsies owing to the limited amount of tissues with too little solid component [11]. Accordingly, Boriani et al. [7] suggested open biopsy and frozen section at the time of surgical resection [7].

Due to the complex nature of the anatomy surrounding the spine, either piecemeal resection or curettage is the most widely used treatment methods in such cases [3,7]. Thus a major issue in their management is that of recurrence. Papagelopoulos et al. [3] reported recurrence in $12 \%$ of his cases treated with intralesional procedures (6 out of 52). De Kleuver et al. [12] reported it in 6 of 29 cases whereas Yang et al. reported a recurrence rate of $30 \%$. The high rate of recurrence was attributed to the incomplete resection $[3,12,13]$. In our series, recurrence occurred in 33\% (2 of 6) needing revision. The ideal surgery to eliminate or decrease such relatively high recurrence rate would be to perform a wide en bloc resection [10]. However such procedure would not always be feasible being dictated by the tumor location. In the cervical spine, sacrificing the vertebral artery might be necessary during wide resection which is controversial. Chao et al. reported no case of recurrence in their series of 14 cervical spine patients following resection or curettage [11].
Selective arterial embolization is used by some prior to surgery in an attempt to decrease intraoperative bleeding [3]. However, in the series presented by Chao et al. [11] where he performed embolization in some but not in all the cases, no statistically significant difference could be found between them. Some authors also reported embolization as a sole method of treatment with evident success rates [14]. The use of radiotherapy in such patients is not conclusive. While its use is assumed to be effective by some, others reported it to be of no value $[15,16]$. Boriani successfully treated some cases solely by radiation with no recurrence detected [7]. Its use might even be hazardous; a case of postradiation osteosarcoma and another of postradiation chondrosarcoma were reported in some series $[3,13]$. We did not use adjuvant radiotherapy in our series. However, it might be of benefit in patients not fit for surgery or in highly aggressive recurrent cases.

\section{Conclusion}

Proper treatment of $\mathrm{ABC}$ in the cervical spine is essential to achieve favorable outcomes. Piecemeal resection of the lesion combined with decompression and fixation appear to be effective. Attempting total excision of the tumor might yield lower recurrence rates.

\section{References}

1. Ruiter DJ, Van Rijssel TG, Van Der Velde EA (1977) Aneurysmal bone cysts: a clinicopathological study of 105 cases. Cancer 39(5): 22312239.

2. Leithner A, Windhager R, Lang S, Haas O, Kainberger F, et al. (1999) Aneurysmal bone cyst. A population based epidemiologic study and literature review. Clin Orthop Relat Res 363: 176-179.

3. Papagelopoulos PJ, Currier BL, Shaughnessy WJ, Sim FH, Ebsersold MJ et al. (1998) Aneurysmal bone cyst of the spine: management and outcome. Spine 23(5): 621-628.

4. Zileli M, Isik HS, Ogut FE, Is M, Caggli S, et al. (2013) Aneurysmal bone cysts of the spine. Eur Spine J 22(3): 593-601.

5. Hay MC, Paterson D, Taylor TK (1978) Aneurysmal bone cysts of the spine. J Bone Joint Surg Br 60: 406-411. 
6. Tsai JC, Dalinka MK, Fallon MD, Zlatkin MB, Kressel HY (1990) Fluidfluid level: a nonspecific finding in tumors of bone and soft tissue. Radiology 175(3): 779-782.

7. Boriani S, De Iure F, Campanacci L, Gasbarrini A, Bandiera S, et al (2001) Aneurysmal bone cyst of the mobile spine: report on 41 cases. Spine 26(1): 27-35.

8. Pennekamp W, Peters S, Schinkel C, Kuhnen C, Nicolas V, et al. (2008) Aneurysmal bone cyst of the cervical spine. Eur Radiol 18: 235-2360.

9. Mankin HJ, Hornicek FJ, Ortiz Cruz E, Villafuerte J, Gebhardt MC (2005) Aneurysmal bone cyst: a review of 150 patients. J Clin Oncol 23(27): 6756-6762.

10. Saccomanni R (2008) Aneurysmal bone cyst of spine: a review of literature. Arch Orthop Trauma Surg 128(10): 1145-1147.

11. Chao W, Xiaoguang L, Liang J, Shaomin Y, Feng W, et al. (2014) Treatments for primary aneurysmal bone cysts of the cervical spine: experience of 14 cases. Chin Med J 127(23): 4082-4086.

This work is licensed under Creative Commons Attribution 4.0 License DOI: $10.19080 /$ OROAJ.2017.09.555767
12. De Kleuver M, Van der Heul RO, Veraart BEEMJ (1998) Aneurysmal bone cyst of the spine: 31 cases and the importance of the surgical approach. J Pediatr Orthop B 7(4): 286-292.

13. Yang C, Ma JM, Yang MS Xiao JR, Yang XH, et al. (2008) Surgical treatment and prognosis of aneurysmal bone cyst in mobile spine. Chin J Surg 46(8): 584-587.

14. Amendola L, Simonetti L, Simoes CE, Bandiera S, De Iure F, et al. (2013) Aneurysmal bone cyst of the mobile spine: the therapeutic role of embolization. Eur Spine J 22(3): 533-541.

15. Capanna R, Albisinni U, Picci P, Calderoni P, Campanacci M, et al. (1985) Aneurysmal bone cyst of the spine. J Bone Joint Surg Am 67: 527-531.

16. Nobler MP, Higinbotham NL, Phillips RF (1968) The cure of aneurysmal bone cyst. Irradiation superior to surgery in an analysis of 33 cases. Radiology 90(6): 1185-1192.

\section{Your next submission with Juniper Publishers will reach you the below assets}

- Quality Editorial service

- Swift Peer Review

- Reprints availability

- E-prints Service

- Manuscript Podcast for convenient understanding

- Global attainment for your research

- Manuscript accessibility in different formats

( Pdf, E-pub, Full Text, Audio)

- Unceasing customer service

Track the below URL for one-step submission https://juniperpublishers.com/online-submission.php 